\title{
New Cocrystal of Ubiquinol with high Stability to Oxidation
}

Lídia Bofill $*$, Dafne de Sande ${ }^{\dagger}$, Rafael Barbas ${ }^{\dagger}$ and Rafel Prohens ${ }^{* \dagger, \ddagger}$

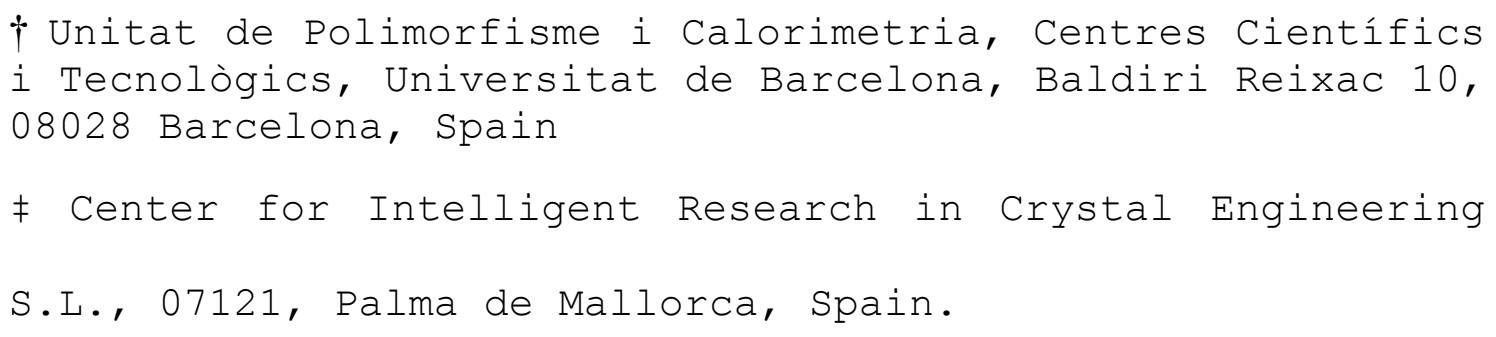

\section{Electronic Supplementary Information}

Table of contents:

1. Experimental methods..........................................

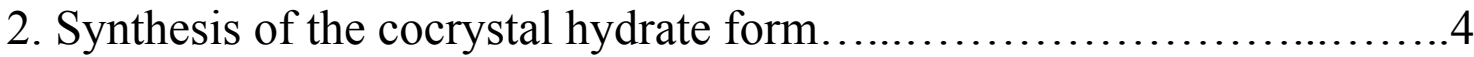

3. Characterization of the solids.........................................................

4. CSD 3,4-Dihydroxybenzoic acid crystal forms reported..............19

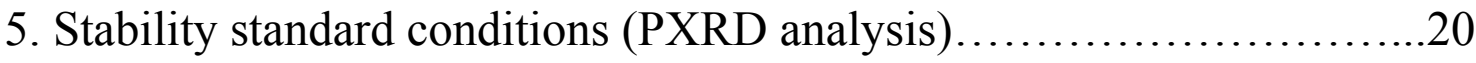

6. References................................................. 25 


\title{
1. Experimental methods
}

\author{
1.1. Solubility qualitative determination of Ubiquinol ( $\mathrm{CoQ}_{10^{-}}$ \\ $\mathrm{H}_{2}$ )
}

The solvents selected to be used in the cocrystal screening are highlighted in black.

$\mathrm{CoQ}_{10}-\mathrm{H}_{2}(20 \mathrm{mg}, 0.023 \mathrm{mmol})$ was dissolved in 30 solvents in a temperature range of $25-50{ }^{\circ} \mathrm{C}$. Ubiquinol is soluble at $25{ }^{\circ} \mathrm{C}$ in the following solvents: ethanol $(1.5 \mathrm{~mL})$, IPA $(1.4 \mathrm{~mL})$, butanol $(0.3 \mathrm{~mL})$, MEK $(0.05 \mathrm{~mL})$, acetone $(0.15 \mathrm{~mL})$, MiBK $(0.05 \mathrm{~mL})$, DMF $(0.05 \mathrm{~mL})$, pentane $(0.05 \mathrm{~mL})$, heptane $(0.1 \mathrm{~mL})$, cyclohexane $(0.05 \mathrm{~mL})$, toluene $(0.05 \mathrm{~mL})$, xylene $(0.05 \mathrm{~mL})$, AcOEt $(0.05 \mathrm{~mL})$, diethyl ether $(0.05 \mathrm{~mL})$, THF $(0.05$ $\mathrm{mL})$, dimethyl ethylene glycol $(0.05 \mathrm{~mL})$, diisopropyl ether $(0.05 \mathrm{~mL})$, dioxane $(0.05$ $\mathrm{mL})$, dichloromethane $(0.05 \mathrm{~mL})$, chloroform $(0.05 \mathrm{~mL})$ and benzyl alcohol $(0.15 \mathrm{~mL})$ and diethylamine $(0.2 \mathrm{~mL})$. At $40^{\circ} \mathrm{C}$ it is soluble in acetic acid $(1.3 \mathrm{~mL})$. At $50^{\circ} \mathrm{C}$ it is soluble in methanol $(2.0 \mathrm{~mL})$, formic acid $(2.0 \mathrm{~mL}), \mathbf{A C N}(2.0 \mathrm{~mL})$ and DMSO $(2.0$ $\mathrm{mL})$. It is insoluble in ethylene glycol and water. It decomposes in $\mathrm{NH}_{3}(32 \%)$ in water and diethylamine. 
1.2. Cocrystal screening experimental procedures

\section{Table S1. Cocrystal screening of $\mathrm{CoQ}_{10}-\mathrm{H}_{2}$}

\begin{tabular}{|c|c|c|c|c|c|c|}
\hline Methodology & Coformers & $\mathrm{N}^{\mathrm{o}}$ Experiments & $\mathrm{N}^{\mathrm{o}}$ Solids & Positive results $^{\circ}$ & Coformers & Form obtained (according to PXRD) \\
\hline Solubility Study & - & 30 & 30 & 1 & - & Anhydrous forms A \\
\hline Net grinding at $25^{\circ} \mathrm{C}$ & 4 & 4 & - & - & - & - \\
\hline Liquid assisted grinding at $25^{\circ} \mathrm{C}$ & 11 & 75 & 67 & 1 & 6 & 6 new evidences \\
\hline Reaction Crystallization at $25^{\circ} \mathrm{C}$ & 9 & 46 & 43 & $1 / 2$ & $2 / 3$ & $\begin{array}{c}\mathrm{CoQ}_{10}-\mathrm{H}_{2}-3,4-\mathrm{DHBA}-\mathrm{H}_{2} \mathrm{O}, \mathrm{CoQ}_{10}-\mathrm{H}_{2}-3,5- \\
\text { DHBA and } \mathrm{CoQ}_{10}-\mathrm{H}_{2}-3-\mathrm{HBA}\end{array}$ \\
\hline Solvent mediated transformation at $25^{\circ} \mathrm{C}$ & 5 & 17 & 16 & $1 / 2$ & $1 / 2$ & $\begin{array}{c}\mathrm{CoQ}_{10}-\mathrm{H}_{2}-3,4-\mathrm{DHBA}-\mathrm{H}_{2} \mathrm{O} \text { and } \mathrm{CoQ}_{10}-\mathrm{H}_{2}- \\
\text { 3-HBA }\end{array}$ \\
\hline Crystallizations at slow cooling rate & - & 8 & 4 & - & - & - \\
\hline $\begin{array}{l}\text { Preparation of the solid forms: } \\
\text { scale up batches }\end{array}$ & 5 & 45 & 49 & $1 / 2$ & $2 / 3$ & $\begin{array}{c}\mathrm{CoQ}_{10}-\mathrm{H}_{2}-3,4-\mathrm{DHBA}-\mathrm{H}_{2} \mathrm{O}, \mathrm{CoQ}_{10}-\mathrm{H}_{2}-3,5- \\
\text { DHBA and } \mathrm{CoQ}_{10}-\mathrm{H}_{2}-3-\mathrm{HBA}\end{array}$ \\
\hline
\end{tabular}

a (1) positive: $\mathrm{CoQ}_{10}-\mathrm{H}_{2}+$ coformer + new peaks observed in PXRD, (2) positive: cocrystal 


\section{Synthesis of $\mathrm{CoQ}_{10}-\mathrm{H}_{2}-3,4-\mathrm{DHBA}-\mathrm{H}_{2} \mathrm{O}$ cocrystal hydrate}

\section{$(1: 1: 1)$}

Synthesis of a cocrystal hydrate of ubiquinol $\left(\mathrm{CoQ}_{10}-\mathrm{H}_{2}\right)$ and 3,4-dihydroxybenzoic acid $(3,4-\mathrm{DHBA})$ was obtained by reaction crystallization methodology at $25^{\circ} \mathrm{C}$. Details of synthesis are as follows:

Concentrated solution of $\mathrm{CoQ}_{10}-\mathrm{H}_{2}$ in butanol was prepared (50 mg in $0.8 \mathrm{~mL}$ ). 3,4DHBA was added until suspension was observed. The suspension was stirred overnight at room temperature $\left(25^{\circ} \mathrm{C}\right)$. The solid was filtered and dried under vacuum. The same cocrystal was also obtained by reaction crystallization in AcOEt instead of butanol.

Its PXRD diagram has been indexed. Stoichiometry has been assessed based on NMR and TGA measurements and EA determination since its crystal structure has not been solved. Thus, its molar ratio $\left[\mathrm{CoQ}_{10}-\mathrm{H}_{2}: 3,4-\mathrm{DHBA}: \mathrm{H}_{2} \mathrm{O}\right]$ is $[1: 1: 1]$. 


\section{3.- Characterization of the solids}

Figure S1: PXRD diffractogram of ubiquinol $\left(\mathrm{CoQ}_{10}-\mathrm{H}_{2}\right)$ raw material

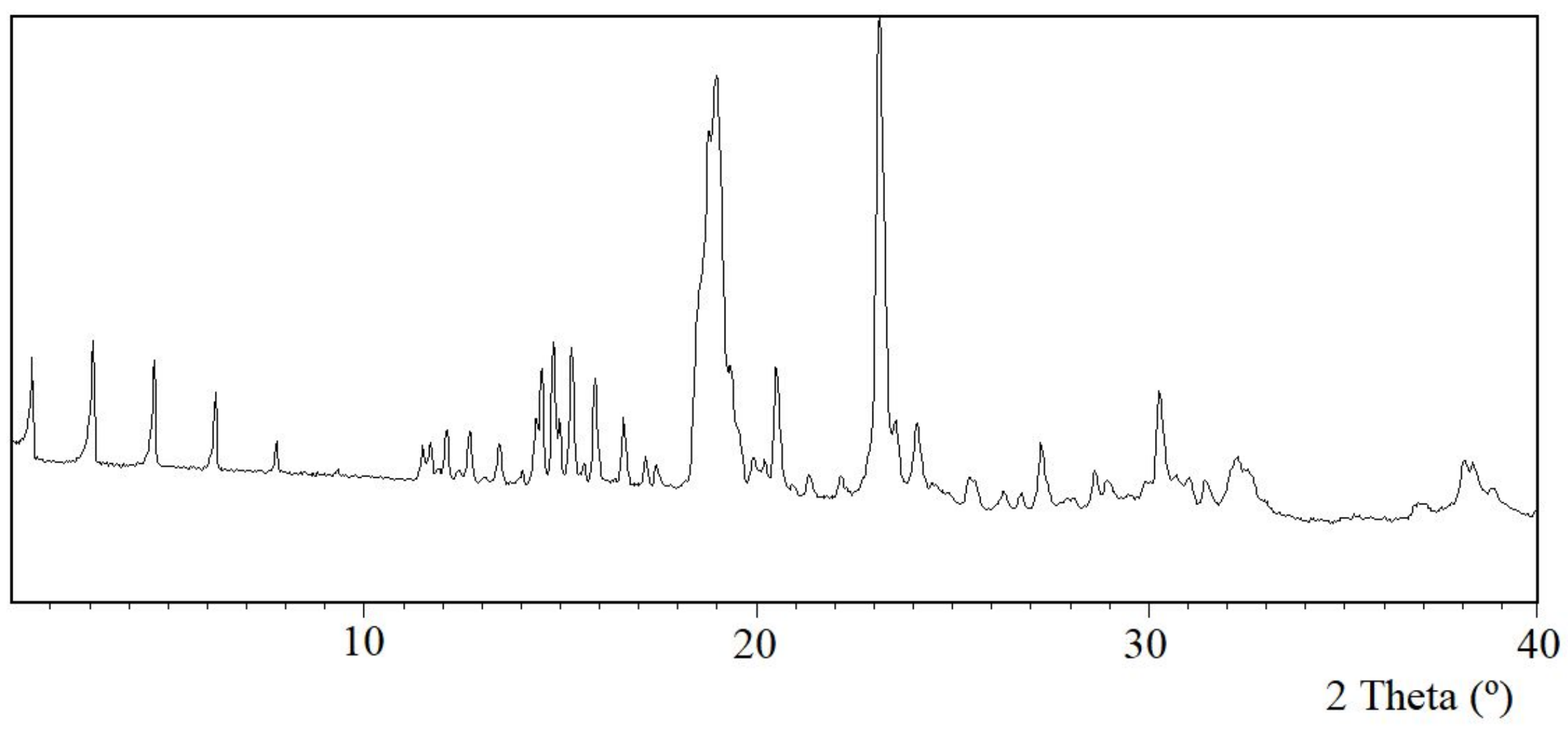


Figure S2: DVS (a) and DVS isotherm (b) of $\mathrm{CoQ}_{10}-\mathrm{H}_{2}: \mathrm{T}^{\mathrm{a}}: 25.3{ }^{\circ} \mathrm{C}$; Mass constancy: $0.001 \%$; Time limit for each step: 1440 minutes

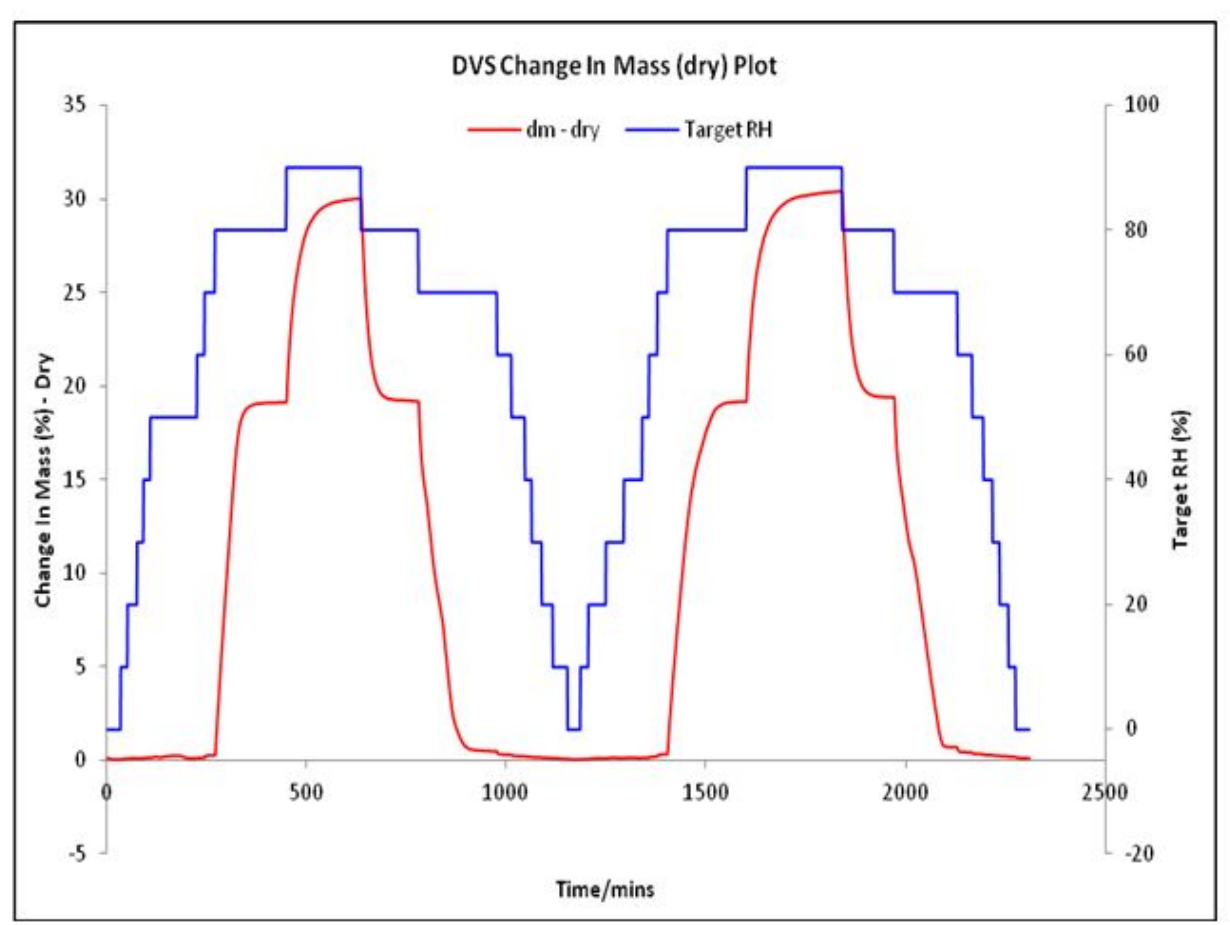

(a)

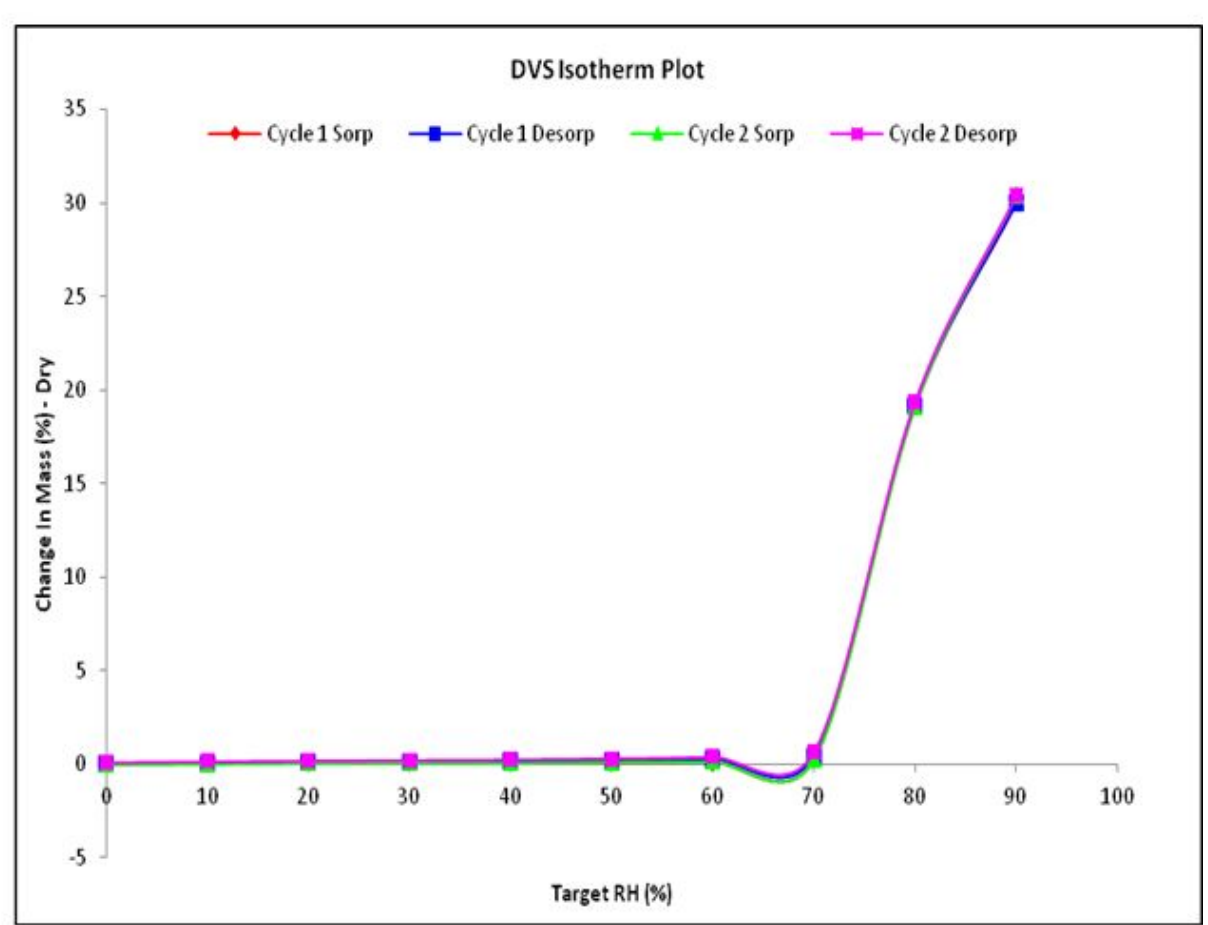

(b) 
Figure S3: DVS (a) and DVS isotherm (b) of $\mathrm{CoQ}_{10}-\mathrm{H}_{2}: \mathrm{T}^{\mathrm{a}}: 40.7^{\circ} \mathrm{C}$; Mass constancy: $0.001 \%$; Time limit for each step: 1440 minutes

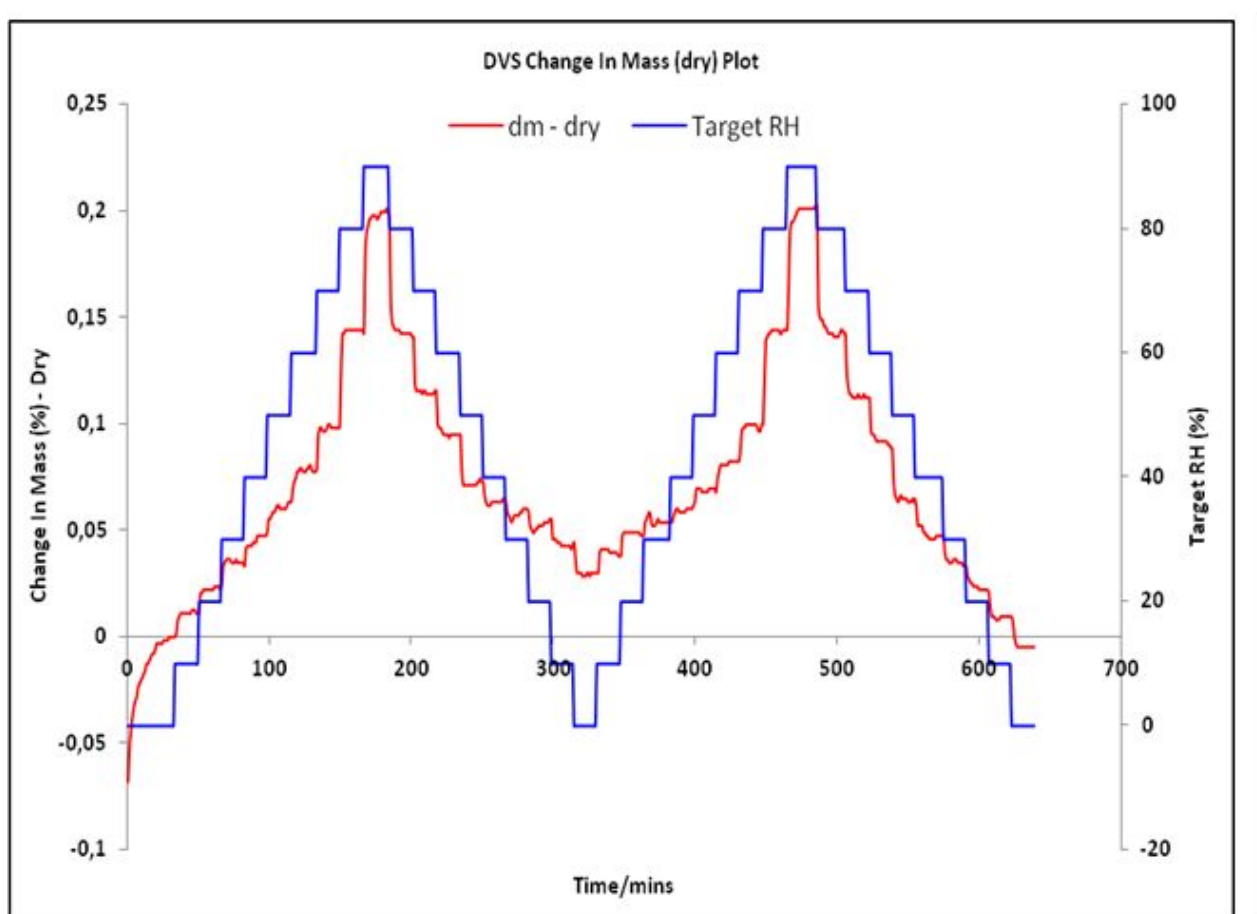

(a)

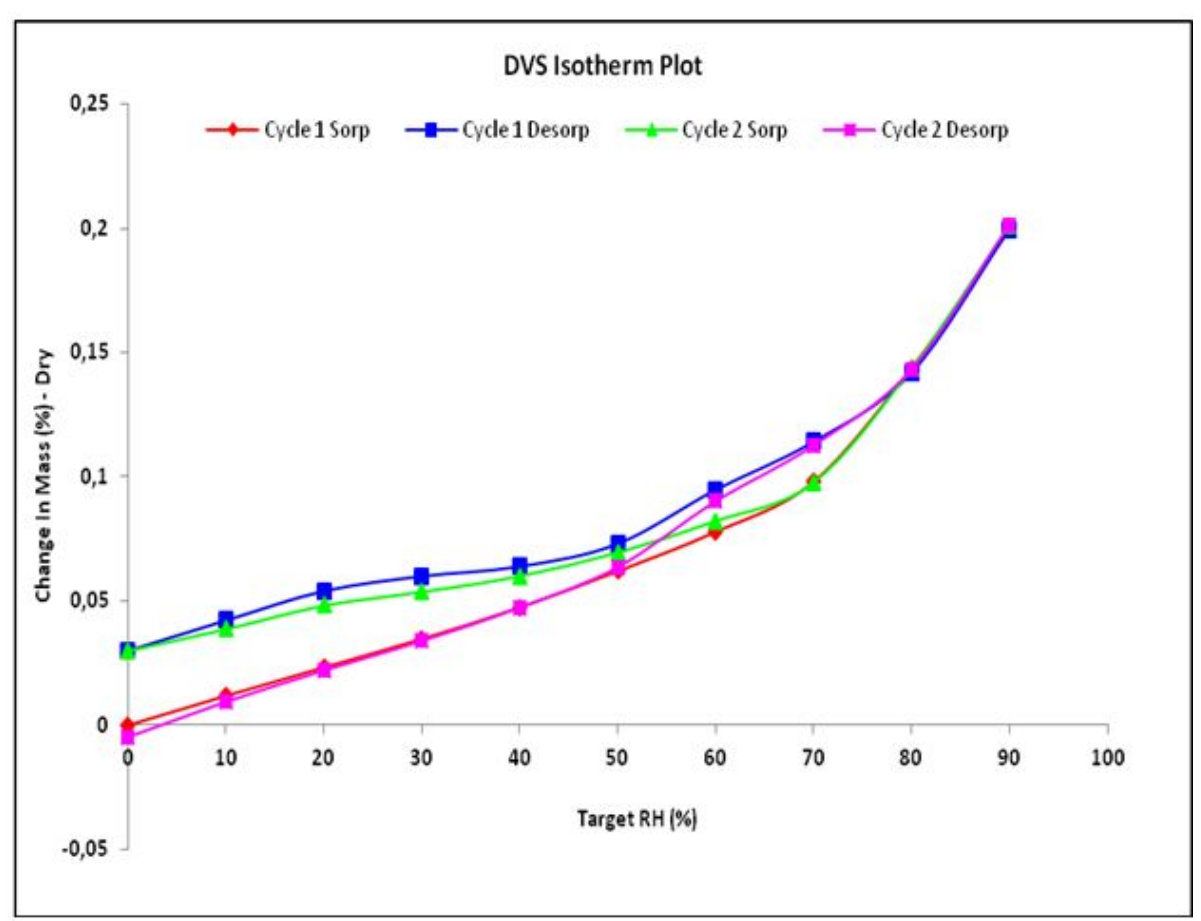

(b) 
Figure S4: Comparative PXRD diffractograms of 3,4-dihydroxybenzoic acid (coformer) (red), simulated from the cif: anhydrous (WUYNUA) (blue) and monohydrates (BIJDON03) (black) and (BIJDON04) (green)

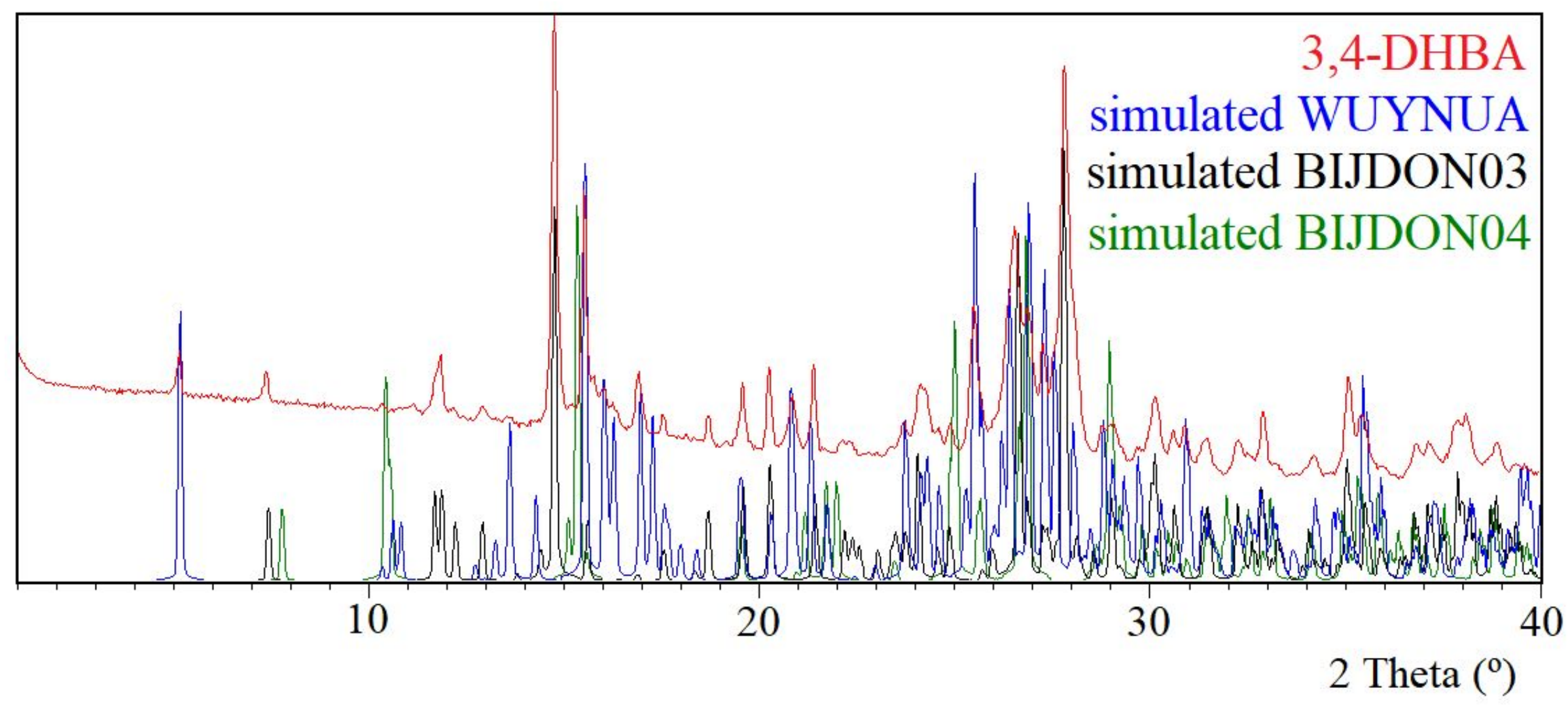


Figure S5: Comparative PXRD diffractograms of ubiquinol $\left(\mathrm{CoQ}_{10}-\mathrm{H}_{2}\right)$ (blue), 3,4-dihydroxybenzoic acid (red) and cocrystal hydrate $\mathrm{CoQ}_{10}-\mathrm{H}_{2}-3,4-\mathrm{DHBA}-\mathrm{H}_{2} \mathrm{O}$ (black)

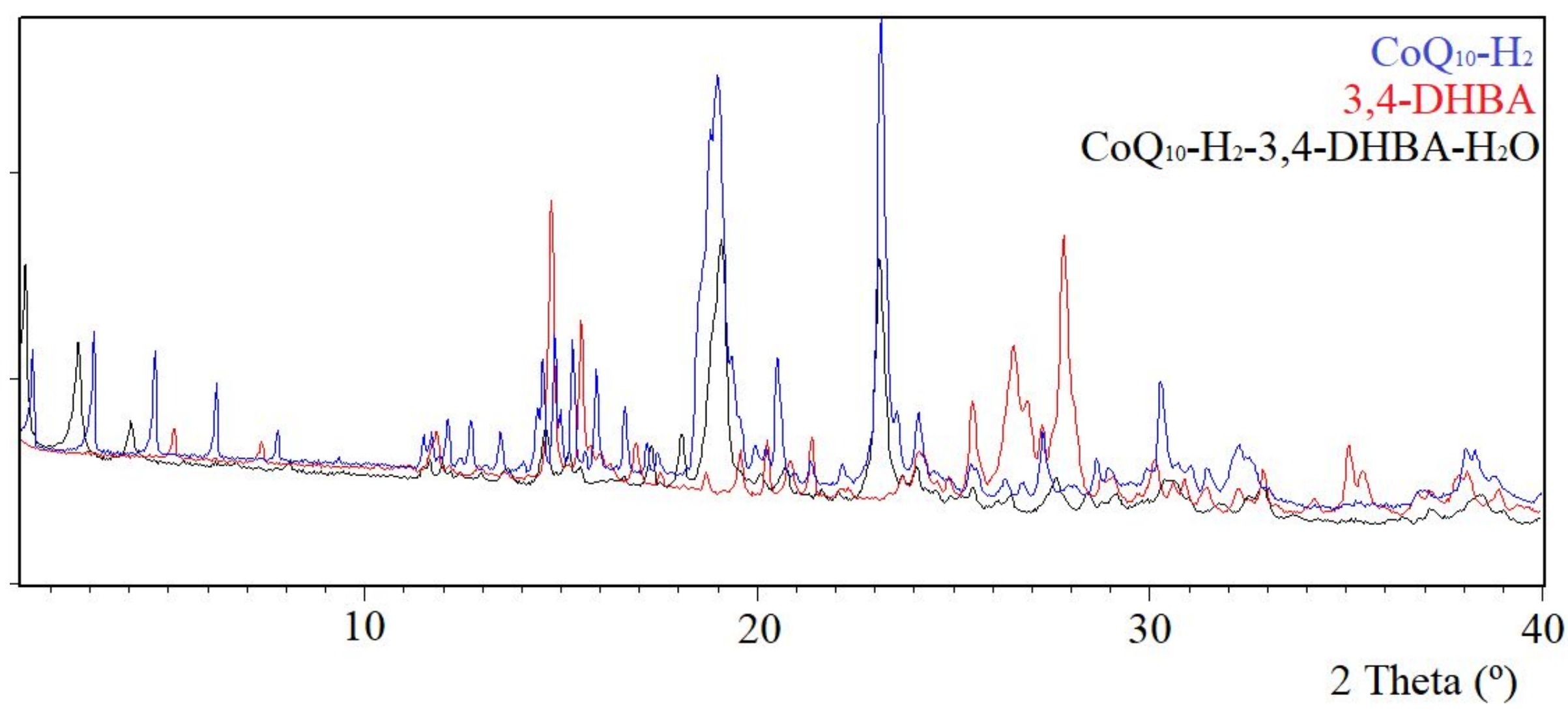


Figure S6: DSC of $\mathrm{CoQ}_{10}-\mathrm{H}_{2}-3,4-\mathrm{DHBA}-\mathrm{H}_{2} \mathrm{O}$

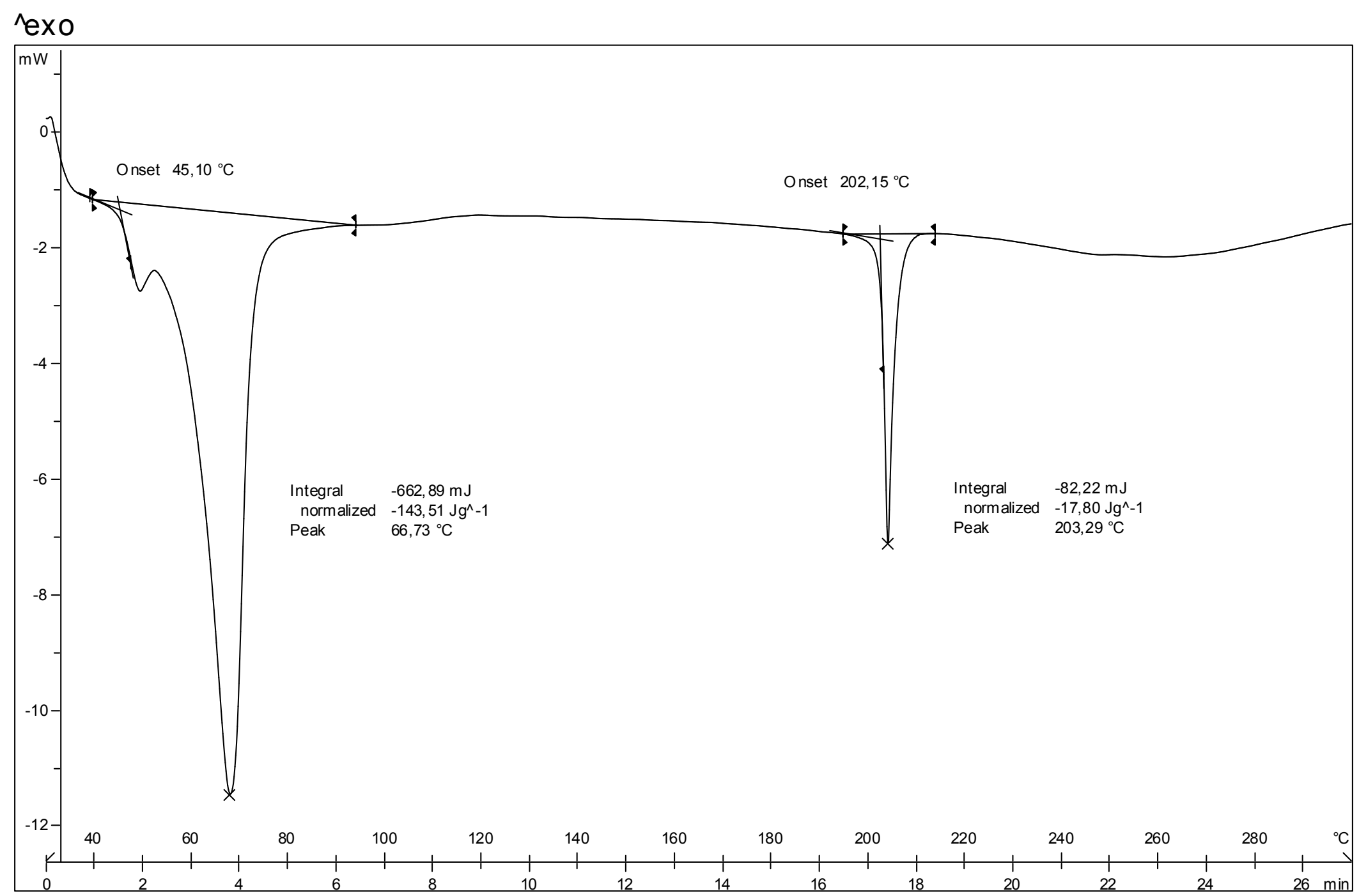


Figure S7: TGA of $\mathrm{CoQ}_{10}-\mathrm{H}_{2}-3,4-\mathrm{DHBA}-\mathrm{H}_{2} \mathrm{O}$ : a weight loss of $1.6 \%$ from $30^{\circ} \mathrm{C}$ to $124{ }^{\circ} \mathrm{C}$ which can be attributed to 1 molecule of water per molecule of ubiquinol and 3,4-dihydroxybenzoic acid (theoretical weight loss of $1.7 \%$ ).

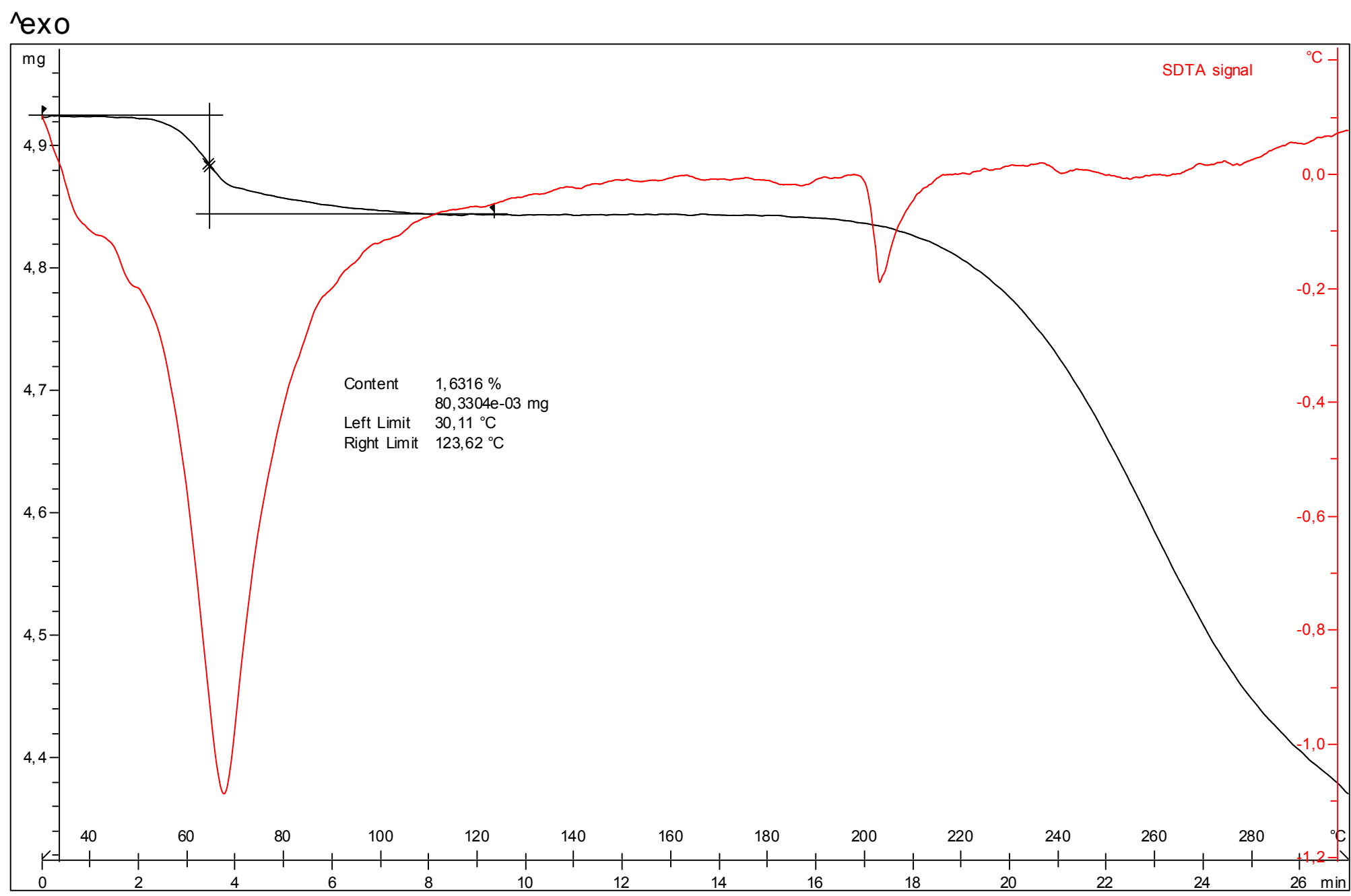


Figure S8: DSC of ubiquinol $\left(\mathrm{CoQ}_{10}-\mathrm{H}_{2}\right)$ used as the raw material

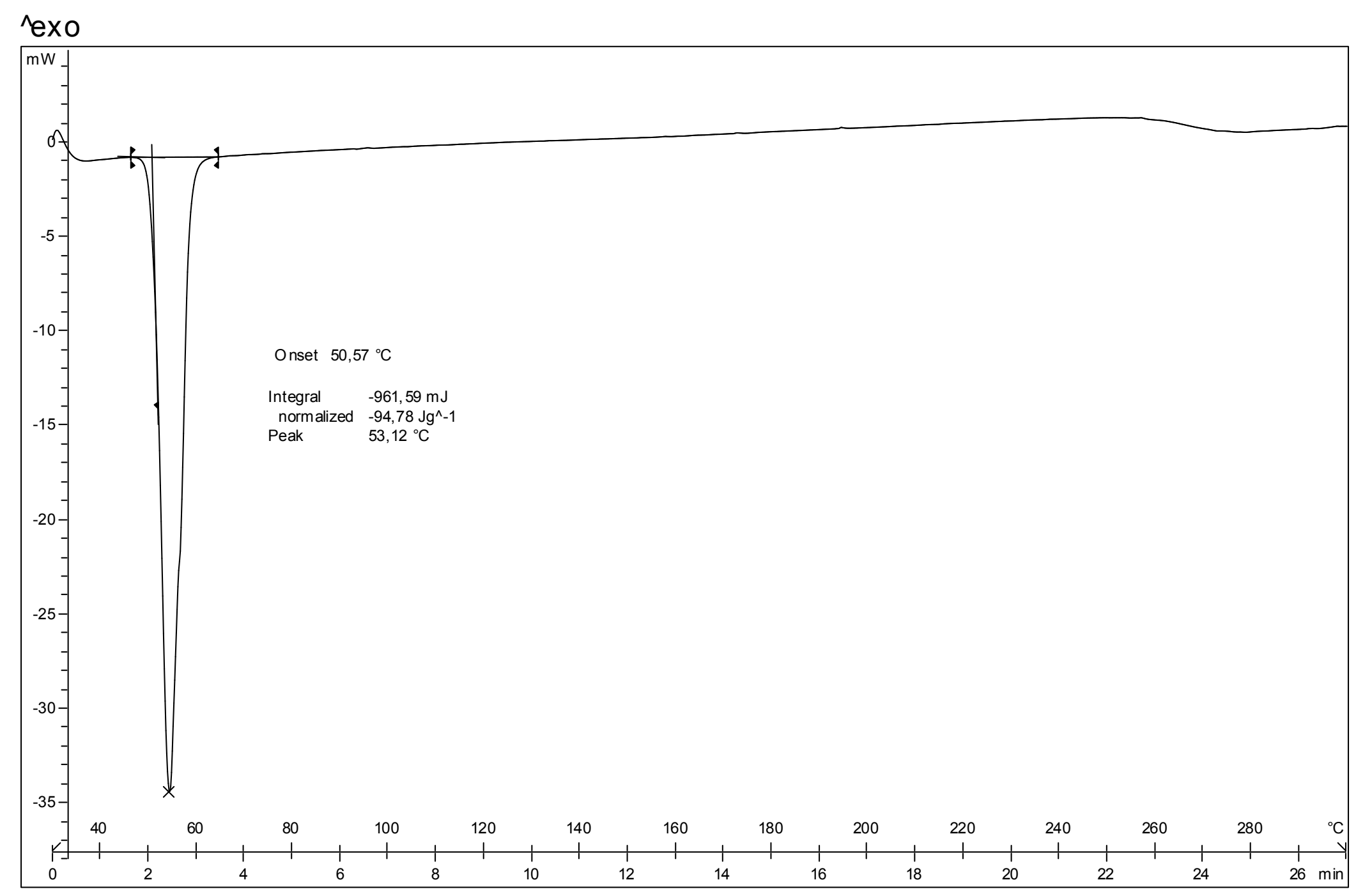


Figure S9: DSC of 3,4-Dihydroxybenzoic acid used as raw material

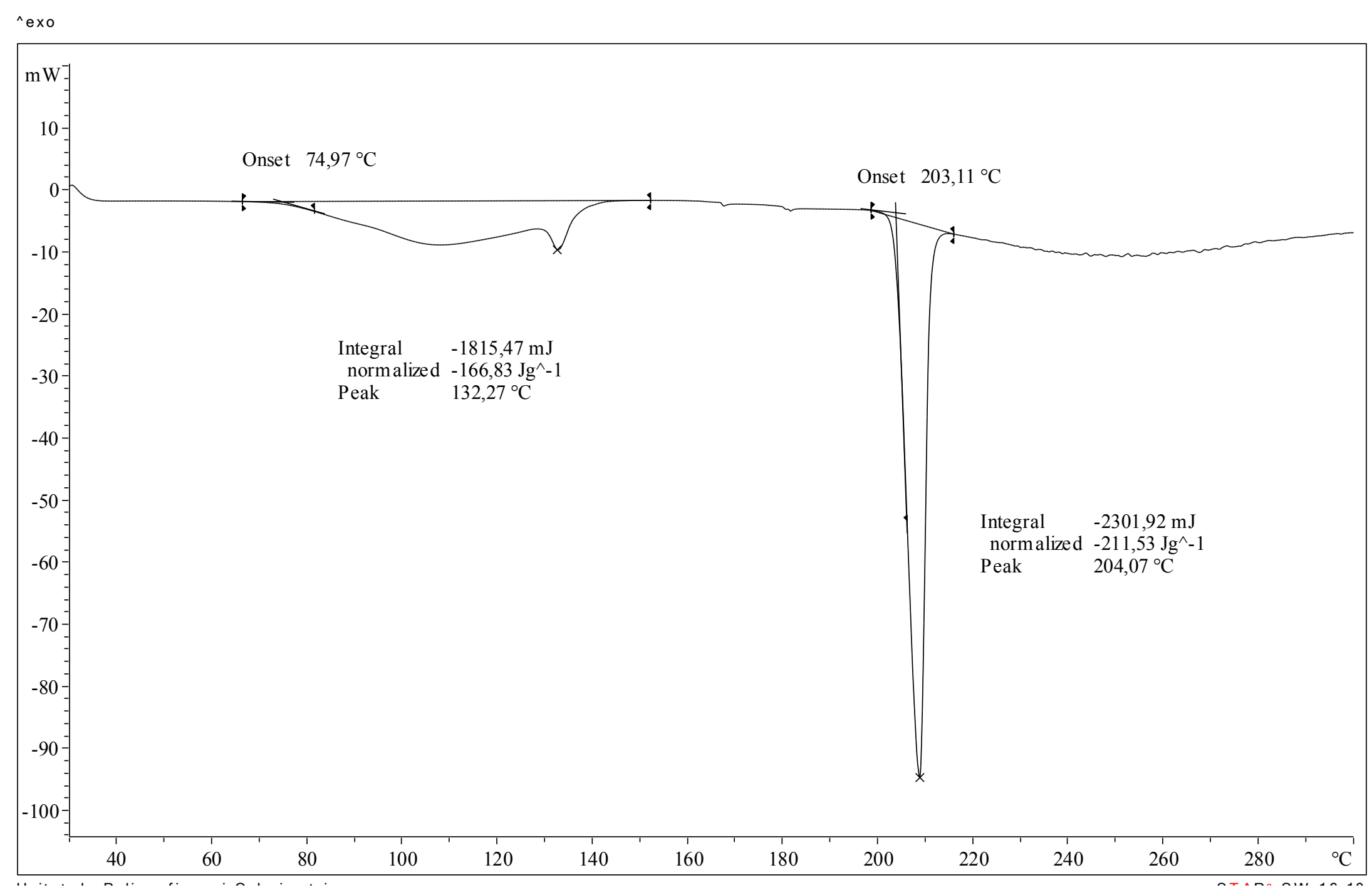


Table S2. Comparative of pure components thermodynamic properties (melting point, $\mathrm{m} . \mathrm{p}$. in ${ }^{\circ} \mathrm{C}$ ) and enthalpy of melting $\left(\Delta \mathrm{H}\right.$ in $\left.\mathrm{Jg}^{-1}\right)$ respect to data reported in literature

\begin{tabular}{ccccc}
\hline \multirow{2}{*}{ Compound } & \multicolumn{2}{c}{ Experimental } & Literature & References \\
\cline { 2 - 5 } & m.p. & $\Delta \mathrm{H}$ & m.p. ${ }^{1}$ & \\
CoQ $_{10}-\mathrm{H}_{2}$ & 51 & 94.8 & 48 and 52 & {$[7]$} \\
& & & & \\
3,4-Dihydroxybenzoic acid & $75^{2}$ & $166.8^{2}$ & $201^{3}$ & {$[1]$} \\
\hline
\end{tabular}

${ }^{1} \Delta \mathrm{H}$ values are not reported

${ }^{2}$ This phenomenon includes dehydration since the starting material is a mixture of anhydrous and monohydrate forms

${ }^{3}$ This corresponds to the anhydrous form 
Figure S10: The PXRD of $\mathrm{CoQ}_{10}-\mathrm{H}_{2}-3,4-\mathrm{DHBA}-\mathrm{H}_{2} \mathrm{O}$ cocrystal hydrate has been indexed with the following proposed monoclinic cell: $a=65.20(2) \AA, b=13.672(7) \AA, c=7.720(3) \AA, \beta=94.96(4)^{\circ}, V=6856(5) \AA 3$ (Figures of Merit: $M=10, F=37$ ), with a number of impurities equal to zero. A $P 2_{1}$ space group is compatible with the cell and the cell volume is compatible with 1 molecule of ubiquinol, 1 molecule of 3,4-dihydroxybenzoic acid and 1 molecule of water at the assymetric unit, $Z=4$. $\left(R_{w p}: 6.62 ; R_{\text {exp }}: 1.82\right)$

WDICVOL04 solution (Automatic generated PCR file) Chi2: 13.2820

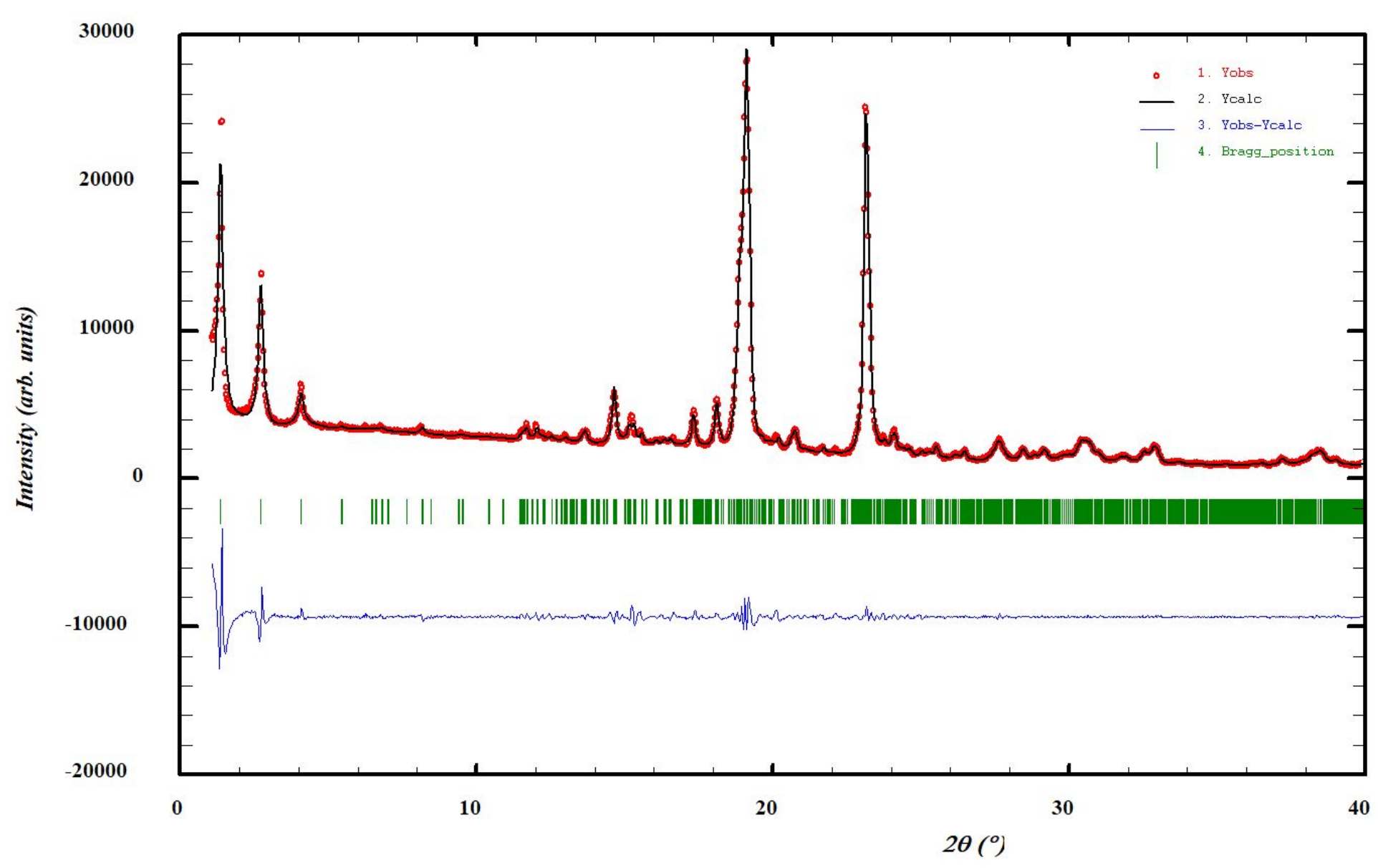


Figure S11: ${ }^{1} \mathrm{H}-\mathrm{NMR}$ (chloroform-d: delay: 1/pulse: 45\%/scans: 32) of $\mathrm{CoQ}_{10}-\mathrm{H}_{2}-3,4-\mathrm{DHBA}-\mathrm{H}_{2} \mathrm{O}$

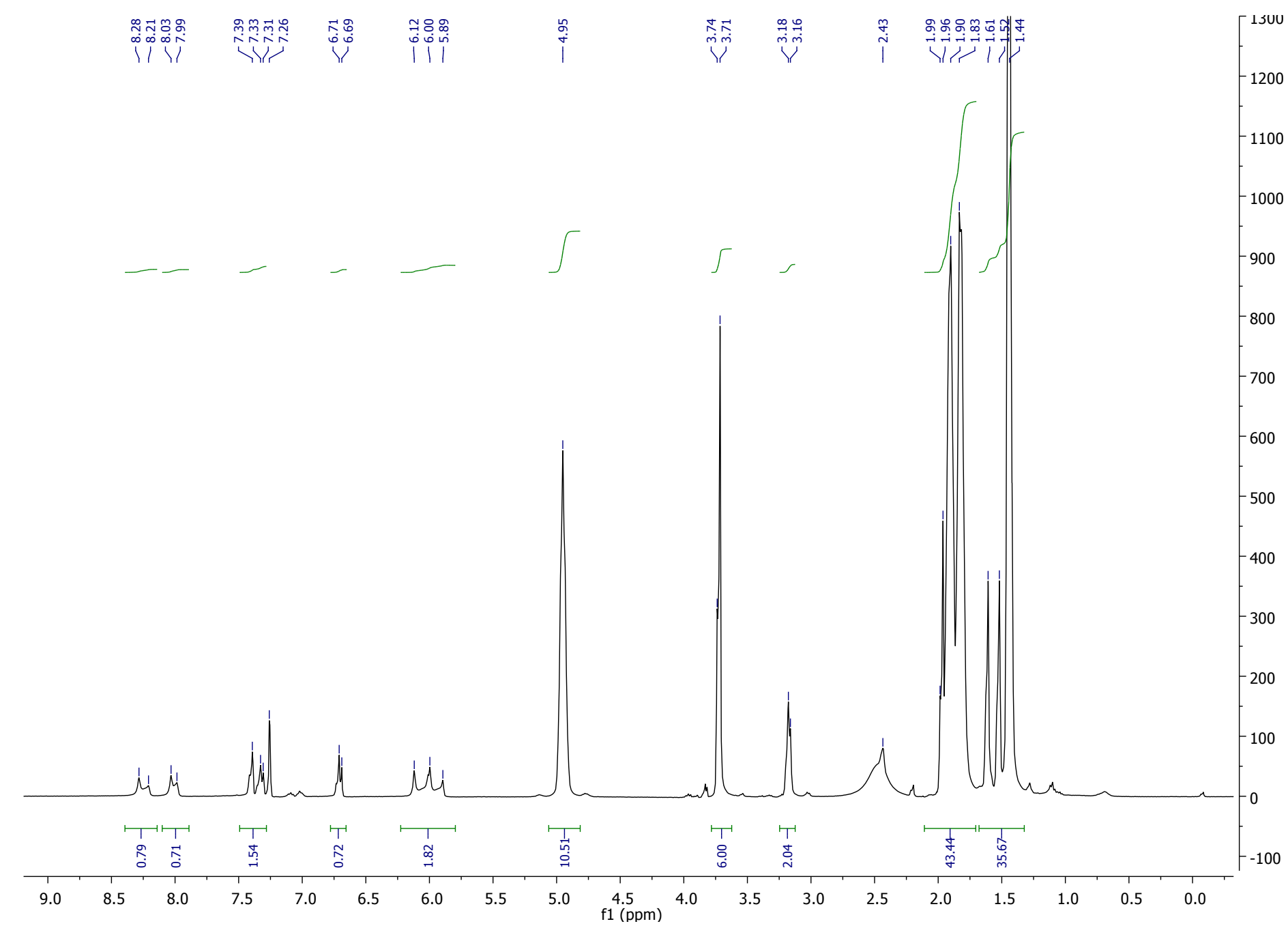


Figure S12: DVS (a) and DVS isotherm (b) $\mathrm{CoQ}_{10}-\mathrm{H}_{2}-3,4-\mathrm{DHBA}-\mathrm{H}_{2} \mathrm{O}: \mathrm{T}^{\mathrm{a}}: 25.3{ }^{\circ} \mathrm{C}$; Mass constancy: 0.001\%; Time limit for each step: 1440 minutes

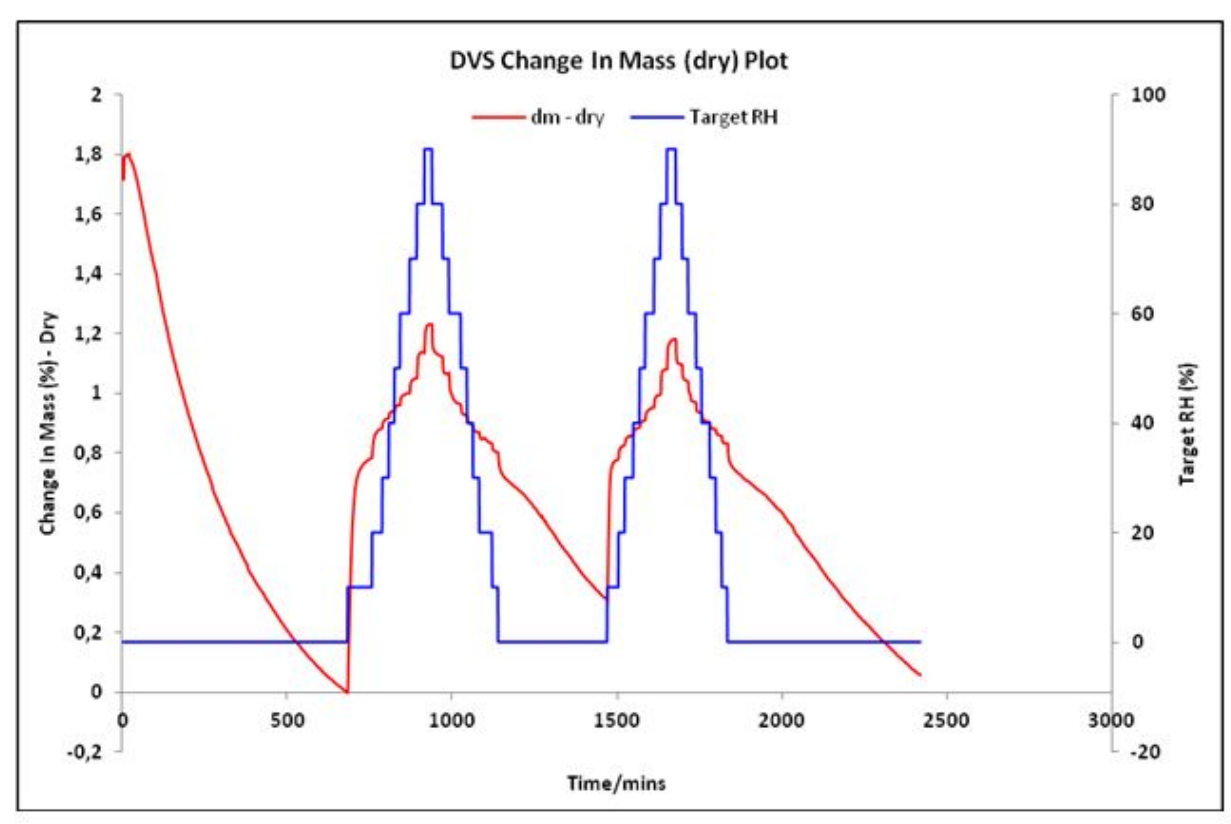

(a)

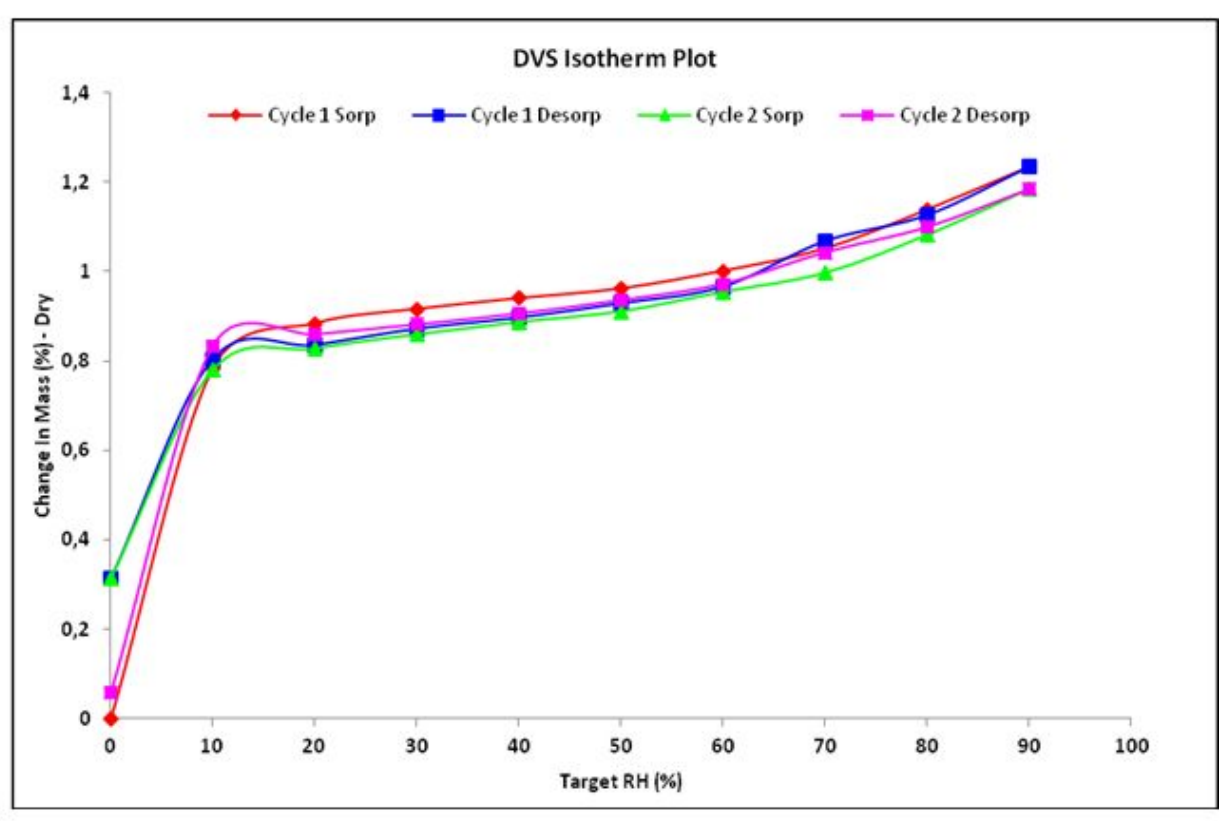

(b) 
Figure S13: Comparative PXRD diffractograms of cocrystal hydrate $\mathrm{CoQ}_{10}-\mathrm{H}_{2}-3,4-\mathrm{DHBA}-\mathrm{H}_{2} \mathrm{O}$ before (black) and after (blue) DVS analysis at $25^{\circ} \mathrm{C}$

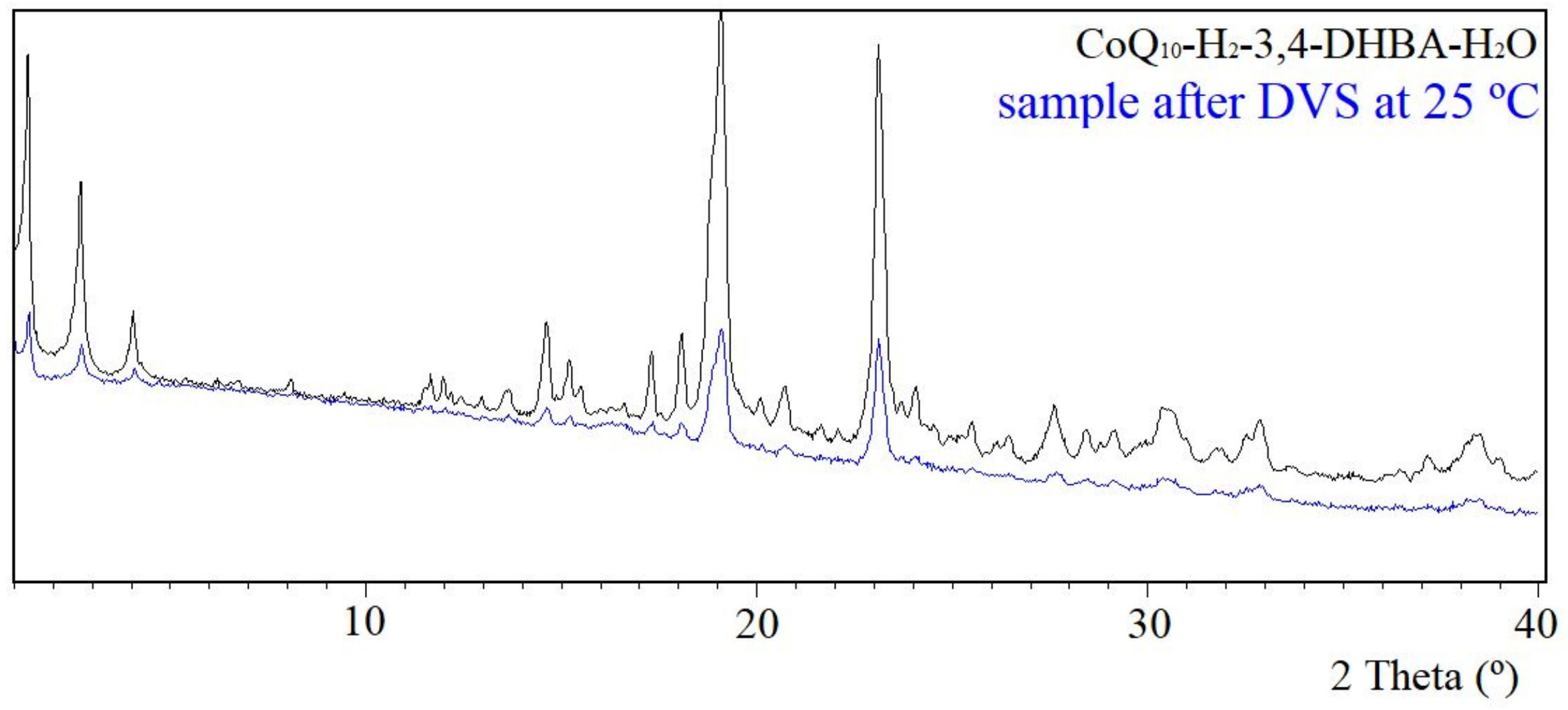


Table S3. Elemental analysis determination

\begin{tabular}{|c|c|c|c|}
\hline \multirow{3}{*}{ EA } & Theoretical e & tal analysis & \multirow{4}{*}{$\begin{array}{c}\text { Experimental elemental analysis } \\
\qquad(\%)\end{array}$} \\
\hline & \multicolumn{2}{|c|}{ Molar ratio } & \\
\hline & $\mathrm{C}_{125} \mathrm{H}_{192} \mathrm{O}_{13}$ & $\mathrm{C}_{66} \mathrm{H}_{100} \mathrm{O}_{9}$ & \\
\hline Element & {$[2: 1: 1]$} & {$[1: 1: 1]$} & \\
\hline $\mathrm{C}$ & 78.90 & 76.41 & 76.07 \\
\hline $\mathrm{H}$ & 10.17 & 9.72 & 10.53 \\
\hline $\mathrm{O}$ & 10.93 & 13.88 & 13.40 \\
\hline
\end{tabular}

\section{4.- CSD 3,4-Dihydroxybenzoic acid crystal forms reported}

37 different crystal forms of 3,4-dihydroxybenzoic acid have been reported in the Cambridge Structural Database (CSD). Among them, one as an anhydrous form, six as monohydrate forms and two solvates (one as an ACN solvate and one as a pyridine solvate), Table S3. Comparative PXRD diffractograms of 3,4-dihydroxybenzoic acid (coformer) and crystal structures reported in CSD are shown in Figure S8.

Table S4. CSD 3,4-Dihydroxybenzoic acid crystal forms

\begin{tabular}{cccc}
\hline Crystal form & CSD refcode & T (K) & References \\
\hline Anhydrous & WUYNUA & 298 & 1 \\
& BIJDON & $295^{\mathrm{a}}$ & 2 \\
& BIJDON01 & $295^{\mathrm{a}}$ & \\
Monohydrate & BIJDON02 & $295^{\mathrm{a}}$ & 3 \\
& BIJDON03 & 293 & 1 \\
& BIJDON04 & 298 & 4 \\
\hline ACN solvate & BIJDON05 & 100 & 5 \\
\hline Pyridine solvate & EDUWUW & 120 & 6 \\
\hline
\end{tabular}

${ }^{a}$ No 3D coordinates available 


\section{5.- Stability standard conditions (PXRD analysis)}

Figure S14: Comparative PXRD diffractograms from 10 to $302 \theta$ of ubiquinol (CoQ 10 -H at time 0 (blue) and after 26 days (red) with ubiquinone (CoQ ${ }_{10}$ ) (green) under standard condition: at $25{ }^{\circ} \mathrm{C}$ and $60 \%$ of relative humidity

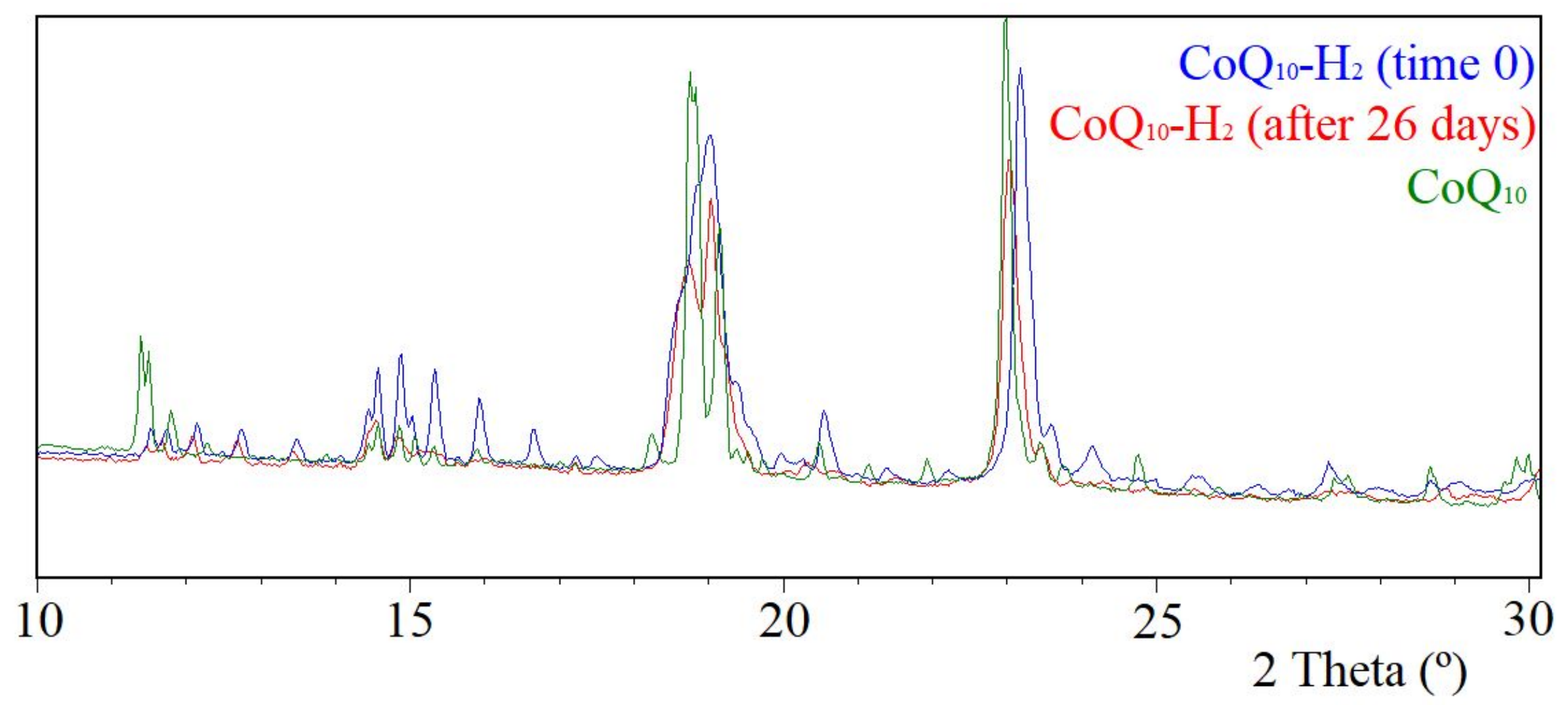


Figure S15: Comparative PXRD diffractograms of cocrystal hydrate $\mathrm{CoQ}_{10}-\mathrm{H}_{2}-3,4-\mathrm{DHBA}-\mathrm{H}_{2} \mathrm{O}$ at time 0 (blue) and after 435 days (red) under standard condition: at $25^{\circ} \mathrm{C}$ and $60 \%$ of relative humidity

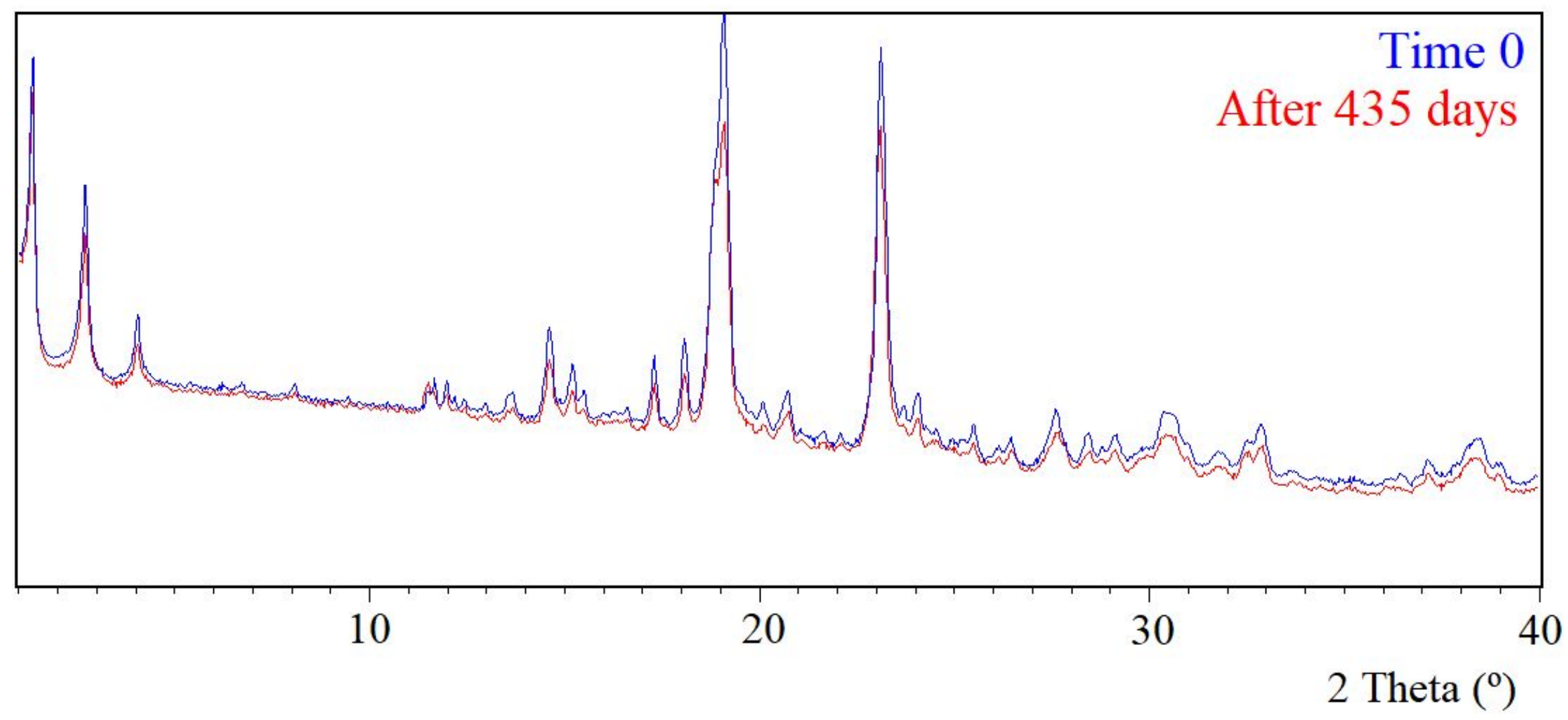


Figure S16: Comparative PXRD diffractograms of cocrystal hydrate $\mathrm{CoQ}_{10}-\mathrm{H}_{2}-3,4-\mathrm{DHBA}-\mathrm{H}_{2} \mathrm{O}$ at time 0 (blue) and after 120 days (red) under standard condition: at $40{ }^{\circ} \mathrm{C}$ and $75 \%$ of relative humidity

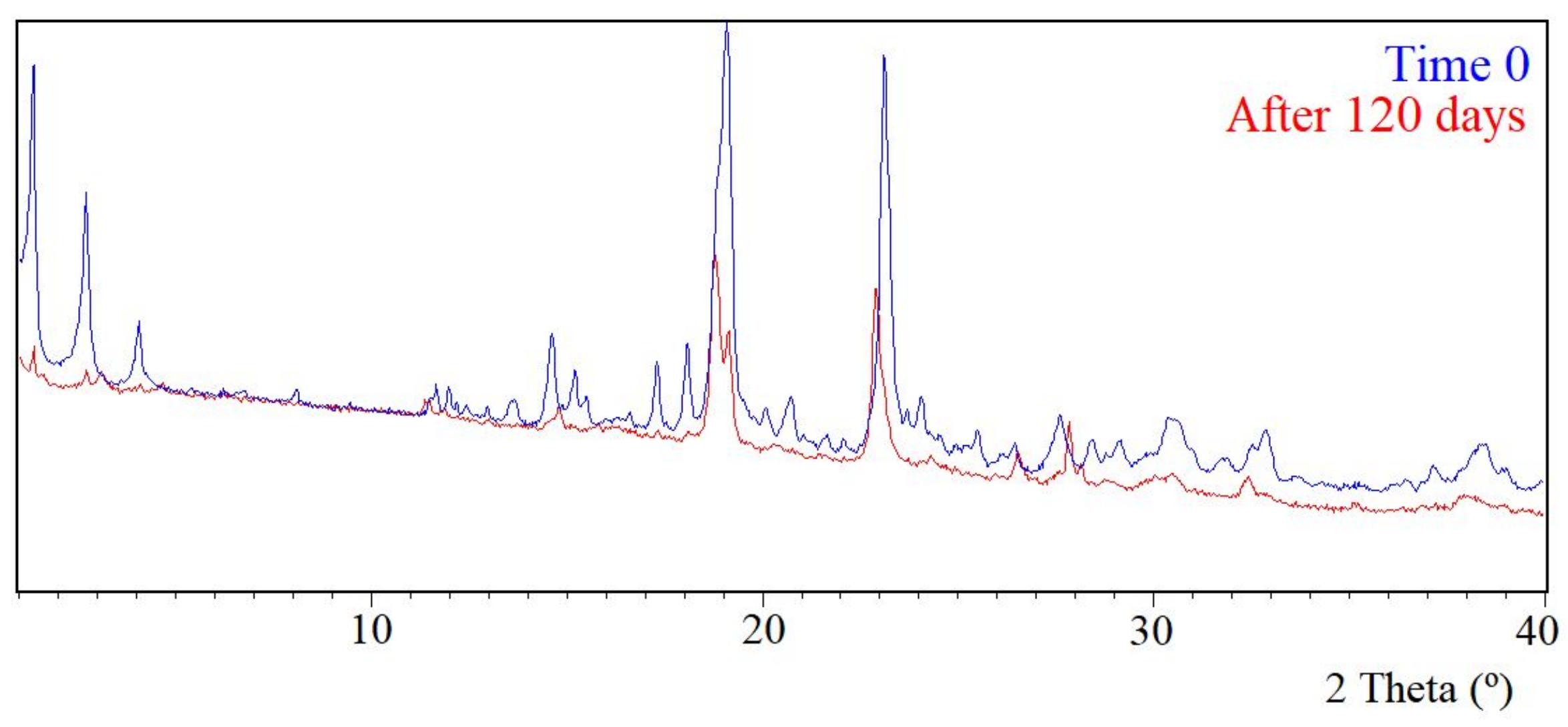


Figure S17: Comparative PXRD diffractograms of cocrystal hydrate $\mathrm{CoQ}_{10}-\mathrm{H}_{2}-3,4-\mathrm{DHBA}-\mathrm{H}_{2} \mathrm{O}$ at time 0 (blue) and after 120 days (red) under standard condition at $40{ }^{\circ} \mathrm{C}$ and $75 \%$ of relative humidity respect to ubiquinol (CoQ ${ }_{10}-\mathrm{H}_{2}$ ) (black) and ubiquinone $\left(\mathrm{CoQ}_{10}\right)$ (green)

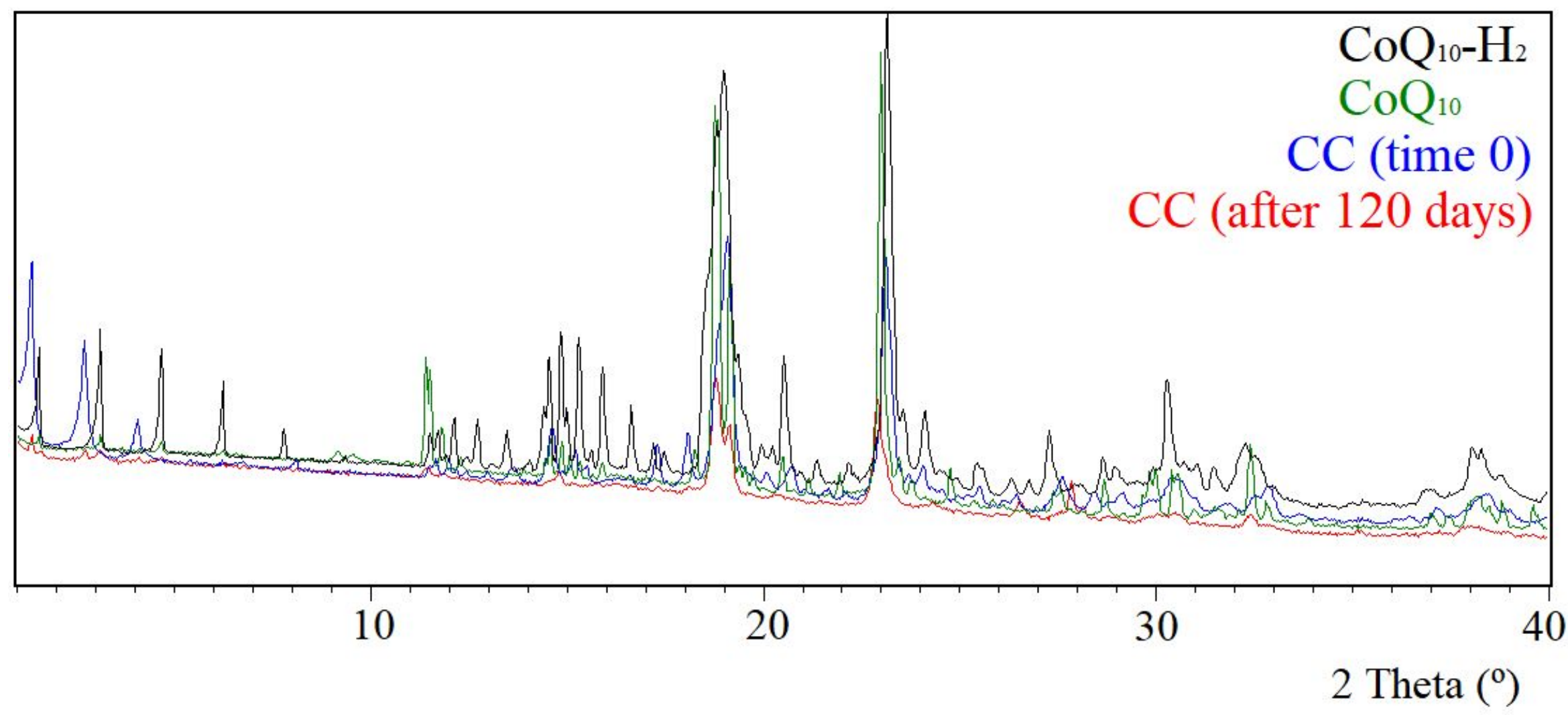


Figure S18: Comparative PXRD diffractograms of cocrystal hydrate $\mathrm{CoQ}_{10}-\mathrm{H}_{2}-3,4-\mathrm{DHBA}-\mathrm{H}_{2} \mathrm{O}$ at time 0 (blue) and after 120 days (red) under standard condition at $40{ }^{\circ} \mathrm{C}$ and $75 \%$ of relative humidity respect to $3,4-\mathrm{DHBA}$ anhydrous (WUYNUA) (black) and monohydrates (BIJDON03) (green) and (BIJDON04) (olive)

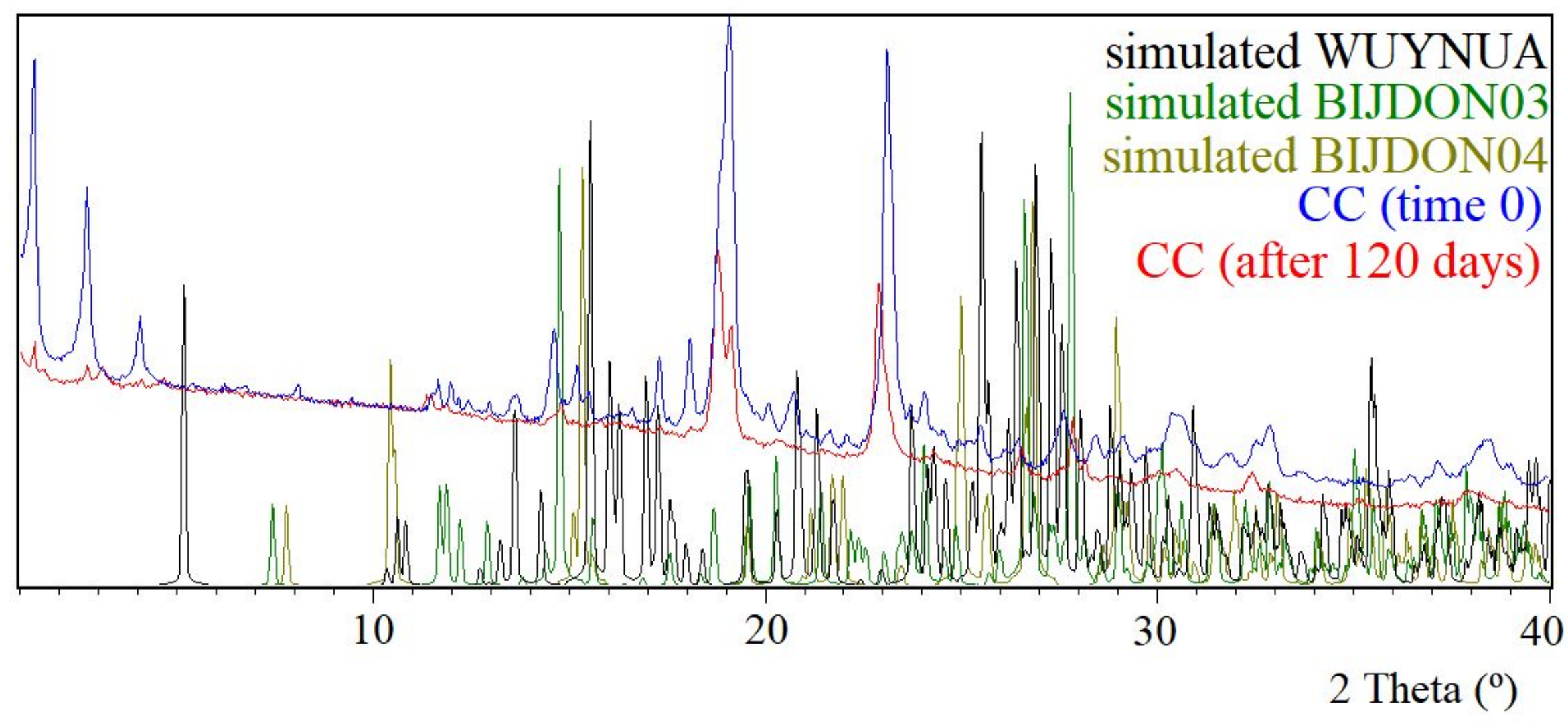




\section{6.- References}

[1] Sarma, B., Sanphui, P., Nangia, A. Polymorphism in Isomeric Dihydroxybenzoic Acids, Crystal Growth \& Design, 2010, 10(5), 2388-2399.

[2] Agmon, I., Herbstein, F. H. Spontaneous deformation of protocatechuic acid monohydrate crystals: crystallographic aspects, Proc. R. Soc. Lond., 1983, A387, 311330 .

[3] Horneffer, V., Dreisewerd, K., Lüdemann, H.-C., Hillenkamp, F., Läge, M., Strupat, $\mathrm{K}$. Is the incorporation of analytes into matrix crystals a prerequisite for matrix-assisted laser desorption/ionization mass spectrometry? A study of five positional isomers of dihydroxybenzoic acid, International Journal of Mass Spectrometry, 1999, 185/186/187, 859-870.

[4] Ng, S. W. A triclinic modification of 3,4-dihydroxybenzoic acid monohydrate, Acta Cryst. 2011, E67, o2476.

[5] Mazurek, J., Dova, E., Helmond, R. 3,4-Dihydroxybenzoic acid acetonitrile solvate at 120 K, Acta Cryst. 2007, E63, o3289.

[6] Zhu, L-C. 3,4-Dihydroxybenzoic acid pyridine monosolvate Acta Cryst., 2010, E66, 03225 .

[7] Method for producing reduced Coenzyme Q10, US2015/0284311A1. Publication date: 8 October 2015, priority JP2012-103687 (27 April 2012). 